Urszula Augustyniak

https://orcid.org/oooo-0003-3527-3159

Warszawa

\title{
Anonimowy poemat ze zbiorów Biblioteki Kórnickiej jako źródło do problemu wdowieństwa w środowisku kalwinistów małopolskich w końcu XVI wieku
}

W artykule dokonano analizy historycznej anonimowego poematu ze zbiorów Biblioteki PAN w Kórniku', opublikowanego w 1891 r. pod zmodernizowanym tytułem przez Zygmunta Celichowskiego ${ }^{2}$. Wydawca ograniczył się do objaśnienia wyrazów staropolskich, a przypisując autorstwo Salomonowi Rysińskiemu, nie dysponowat informacjami dostępnymi obecnie w wyniku postępu badań. Podjęto próbę odczytania dopisków na marginesach, do których nie odniósł się wydawca. W części wstępnej artykułu odniesiono się do kwestii atrybucji utworu i dokonano charakterystyki środowiska, w którym prawdopodobnie powstał. Następnie omówiono poemat pod kątem treści wyznaniowych, przesłania ideowego, sposobu rozpowszechniania oraz przydatności do badania zagadnienia wdowieństwa męskiego w dawnej Rzeczypospolitej.

1 BK, rkps 524, mf 1419, dostępny na platformie cyfrowej BK. Rękopis in quarto, na papierze ze znakiem wodnym z herbem Jelita, pochodzącym prawdopodobnie z czerpalni w Wilczkowicach (własności Wilczkowskich h. Jelita) nad rzeką Dłubnią, w powiecie miechowskim (woj. sandomierskie), gdzie w latach 1586-1620 wyrabiano papier opatrzony tym herbem; zob. K. Nizio, Autorstwo poematu „Stanu wdowiego tęskliwego pobożne zabawy i pociechy”, „Pamiętnik Biblioteki Kórnickiej”, 19, 1982, s. 206. Utwór został napisany duktem szesnastowiecznym. Ponadto w pliku występują liczne, bardzo źle czytelne, zapiski duktem siedemnastowiecznym obcą ręką, nienależącą ani do domniemanego autora, ani znalazcy kopii.

2 Stanu wdowiego tęskliwego pobożne zabawy i pociechy, wyd. Z. Celichowski, Poznań 1891, s. 3-19. 
The article presents a historical analysis of an anonymous poem from the collection of Kórnik Library of the Polish Academy of Sciences, published in 1891 under a modernised title by Zygmunt Celichowski. He contented himself with explaining the Old Polish words and attributed the authorship to Salomon Rysiński, not having the information currently available due to research progress. Presently, an attempt was made to read the notes on the margins the publisher did not refer to. The introductory part of the article addresses the question of the work's attribution and characterises the environment in which the poem could have been written. Then, the poem is discussed in terms of its religious content, ideological message, methods of distribution, and usefulness for the study of widowerhood in the Polish-Lithuanian Commonwealth.

Słow a kluczowe: wdowieństwo, emocje, kalwiniści, bracia polscy, przesłanie ponadwyznaniowe

Ke yw ords: widowerhood, emotions, Calvinists, Polish Brethren, supra-denominational message

Wierszowany utwór Stanu wdowiego tęskliwego pobożne zabawy i pociechy funkcjonuje w obiegu naukowym od czasu jego pierwszej edycji na podstawie kopii zapisanej in quarto na 12 kartach i nabytej w $1821 \mathrm{r}$. przez Zygmunta Celichowskiego od Kajetana Kwiatkowskiego, byłego bibliotekarza księcia Dominika Radziwiłła. Zawiera ona trzynastozgłoskowy poemat Rozmowy i pociechy o stanie wdowim (k. 4rec.-12ver.) oraz poprzedzające go: epigramat $N a$ herb Śreniawa starożytnego domu Wzdowskiego (k. 1ver.-3rec.), dedykację kasztelanowej połanieckiej (k. 3rec.-3ver.) i Do pobożnych sierot przemowe (k. 3ver.) ${ }^{3}$. Wydawca datował powstanie utworu na koniec XVI w. (najwcześniej ok. 1586 r. $)^{4}$, dokonał jego analizy filologicznej i pokrótce omówił treść, a poemat uznał za „utwór o charakterze dydaktyczno-moralnym”. Autorstwo - choć nie bez wątpliwości - przypisał Salomonowi Rysińskiemu na podstawie adnotacji na k. 12: „Wiersze różne między manuscriptami nieboszczyka P. Rysińskiego nalezione od Mierzeńskiego w Popielu 162918 Maia”. Domniemany autor ${ }^{5}$

3 Numeracja stron tu i dalej za rękopisem BK.

4 Z. Celichowski, [Wprowadzenie], w: Stanu wdowiego, s. 5.

5 Salomon Rysiński h. Ostoja (Rysinius Sarmata, Pantherus, Leucorussus, ur. ok. 1560) - wyznawca kalwinizmu, działacz ewangelicko-reformowany, pisarz, tłumacz, filolog i paremiolog, autor Proverbiorum polonicorum [--] centuriae decem et octo (1618). Według starszej literatury urodzony w szlacheckiej wsi 
i znalazca poematu ${ }^{6}$ związani byli z dworem ewangelicko-reformowanej linii Radziwiłłów na Birżach i Dubinkach, po których archiwum przejęła linia katolicka - nieświeska ${ }^{7}$.

Zaproponowana przez Z. Celichowskiego atrybucja Stanu wdowiego została zaakceptowana $\mathrm{w}$ bibliografiach ${ }^{8}$ i starszej literaturze ${ }^{9}$, a także w katalogu rękopisów Biblioteki PAN w Kórniku ${ }^{10}$ oraz w najnowszym opracowaniu poświęconym paremiologowi ${ }^{11}$. Zakwestionowała ją jednak bibliotekarka kórnicka Krystyna Nizio ${ }^{12}$, odwołując się do następujących argumentów ${ }^{13}$ :

1. rękopis nie jest autorstwa Rysińskiego - zachowała się tylko kopia, a gdyby Rysiński był autorem pozostawiłby zapewne w swoich papierach autograf. W dotychczasowych badaniach nie udało się

Rysinie koło Połocka, syn drobnego szlachcica Fedora. Na podstawie nowych ustaleń, wątpliwego pochodzenia, urodzony w miasteczku Kobylniki (dzisiejsza Narocz, pow. oszmiański) lub w majętności Kobylniki (woj. witebskie). W 1568 r. przebywał w Altdorfie, a następnie w Pradze i Lejdzie (1594-1596). Od lat 1596-1597 związany z Radziwiłłami birżańskimi najpierw jako wychowawca, a później doradca Krzysztofa II Radziwiłła (1585-1640), któremu towarzyszył podczas jego podróży i studiów w Niemczech (1601-1603); następnie jako nauczyciel jego syna Janusza. Po powrocie do Rzeczypospolitej przebywał najczęściej w Wilnie. Zgromadził dużą bibliotekę, zawierającą głównie dzieła o treści religijnej. Zmarł w 1625 r. w Dolatyczach nad Niemnem, w majątku Daniela Naborowskiego. Informacje biograficzne za: H. Lulewicz, Rysinski Salomon, PSB, 33, 1991-1992, s. 553-557.

6 Jan Mierzeński h. Leliwa (zm. 1665) - marszałek wiłkomierski (1653-1665), podstoli wołkowyski (1648), starosta wasilkowski (1650), marszałek sejmiku pow. wiłkomierskiego (1664), dyplomata, działacz ariański, od 1661 r. kalwinista. Żonaty z Zofią z Wyssogotów-Zakrzewską; zob. T. Wasilewski, Mierzeński Jan, PSB, 21, 1976, s. 18-20.

7 Świadczy o tym dawna sygnatura archiwalna na k. 12, odpowiadająca sygnaturom Archiwum Radziwiłłów z Nieświeżu (obecnie w AGAD w Warszawie): N. 2 Fasc. 22 Manuscripta.

8 Por. K. Estreicher, Bibliografia polska XIX stulecia lata 1881-1900, t. 1-4, Kraków 1906-1916; Bibliografia literatury polskiej „Nowy Korbut”, t. 3, red. K. Budzyk, Warszawa 1963.

9 Por. W. Korotyński Salomon Rysinski. Studjum, wyd. A. H. Kirkor, Wilno 1863.

10 Por. Katalog rękopisów staropolskich Biblioteki Kórnickiej XVI-XVIII w., t. 5: Literaria, oprac. A. Mężyński, Kórnik 1992, s. 181.

11 Por. R. Grześkowiak, „Próżno się kusić, czym nie dano być”. Jak Salomon Rysiński pasowat Biernata z Lublina na pierwszego paremiologa Rzeczypospolitej, w: Biernat $z$ Lublina a literatura $i$ kultura wczesnego renesansu $w$ Polsce, wyd. J. Dąbkowska-Kujko, A. Nowicka-Struska, Lublin 2015, s. 146.

12 Por. K. Nizio, op. cit., s. 206-212.

13 Ibidem, s. 210. 
wykazać żadnych powiązań Rysińskiego z domem kasztelana połanieckiego Andrzeja Niedrwickiego, zmarłego męża adresatki dedykacji ${ }^{14}$;

2. pochodzenie papieru, nazwiska osób wymienionych w dopiskach na tekście oraz pewne cechy językowe przemawiają za małopolskim rodowodem autora;

3. po przyszłym autorze Przypowieści polskich można by się spodziewać większego nasycenia tekstu przysłowiami, podczas gdy w poemacie znajdujemy tylko trzy ich przykłady.

Spośród przytoczonych argumentów przeciw autorstwu Rysińskiego jeden wydaje się nieodparty: zachowanie kopii wiersza w spuściźnie po nim nie dowodzi autorstwa, a dane biograficzne przeczą jego identyfikacji z autorem dedykacji poematu „Jej M. Paniej kasztelanowej połanieckiej” z domu Wzdowskiej herbu Śreniawa, w której mowa o powinowactwie z domem Wzdowskich (vel Zdowskich) „przez dziatki, co poszły z Śreniawy” (k. 2ver.). Wbrew spekulacjom Alojzego Sajkowskiego brak także pewnych dowodów, że Rysiński miał żonę i dzieci ${ }^{15}$. Jego niepewne szlachectwo wyklucza, naszym zdaniem, spowinowacenie z zamożną rodziną Wzdowskich, wzbogaconą dzięki nadanemu im i rodzinie Balów w 1532 r. przywilejowi królewskiemu na poszukiwanie kopalin w ziemiach sanockiej i bieckiej ${ }^{16}$.

14 Andrzej Niedrwicki (Niedrzwicki, Niedźwiedzki) h. Ogończyk (zm. przed 1589) - kasztelan połaniecki; szerzej por. K. Niesiecki, Herbarz Polski, t. 6, wyd. J. N. Bobrowicz, Lipsk 1845, reprint Warszawa 1989, s. 540; ibidem, t. 9, s. 468; T. Żychliński, Ztota ksiegga szlachty polskiej, t. 16, Poznań 1894, s. 233. Według Bartosza Paprockiego (Herby rycerstwa polskiego, wyd. J. K. Turowski, Kraków 1858, s. 523) brał udział w wyprawie Stefana Batorego pod Połock pod komendą hetmana Mikołaja Mieleckiego. Informację tę potwierdza nobilitacja domownika, zapewne za zasługi wojenne, na sejmie 1590 r.; por. Ksiega wpisów kanclerza Jana Zamoyskiego MK 133 z Archiwum Gtównego Akt Dawnych $w$ Warszawie lata 1587-1595, wyd. W. Krawczuk, Kraków 2001 (Sumariusz Metryki Koronnej. Seria Nowa, t. 2), s. 101, nr 2010. Przed otrzymaniem kasztelanii Niedrwicki był podkomorzym sanockim; por. Urzędnicy województwa sandomierskiego XVI-XVIII wieku. Spisy, oprac. K. Chłapowski, A. Falniowska-Gradowska, red. nauk. A. Gąsiorowski, Kórnik 1993, s. 65, nr 392.

15 Por. A. Sajkowski, Od Sierotki do Rybeńki. W kręgu radziwittowskiego mecenatu, Poznań 1965, s. 226, przyp. 17.

16 Por. Studia z dziejów górnictwa i hutnictwa, t. 5, red. J. Pazdur, Warszawa, 1959, s. 147. Związki ekonomiczne Wzdowskich i Balów zostały w XVI w. utrwalone przez małżeństwa zawierane z pannami z rodu Wzdowskich przez Balów i adoptowanych przez nich do herbu Gozdawa Stanów oraz patronat nad zborami ewangelicko-reformowanymi w Hoczewiu i Nowotańcu. 
Wbrew założeniu Z. Celichowskiego i jego następców należy zauważyć, że autor dedykacji poematu wdowie po kasztelanie połanieckim oraz epigramatu na herb Śreniawa nie musiał pisać we własnym imieniu. Oba utwory mogły powstać na zlecenie powinowatych wdowy po Niedrwickim: Krzysztofa Lanckorońskiego Włodzisławskiego (zm. 1591) ${ }^{17}$ lub Jerzego Stano, syna Hieronima Stano i Wzdowskiej ${ }^{18}$. Bardziej prawdopodobny jest Lanckoroński, który odpowiada charakterystyce Gospodarza jako człowieka w podeszłym wieku (k. 3ver., 10ver., 11 rec.). Nie musieli oni nawet angażować wierszopisa minoris gentium do ułożenia poprzedzających poemat utworów - mogli nawet stworzyć je osobiście, bo umiejętność „składania" standardowych tekstów okolicznościowych posiadał wówczas każdy uczeń poetyki.

Podsumowując refleksje na temat atrybucji Stanu wdowiego, wypada zgodzić się z konkluzją K. Nizio:

W świetle wyżej przedstawionych danych autora utworu szukalibyśmy [--] niekoniecznie wśród luminarzy literatury. Złoty wiek wydał także wielu zdolnych rymopisów, autorów jednego dzieła i podobne, zgrabne i pouczające, poemaciki mogły powstawać po kasztelańskich a nawet szlacheckich dworach ${ }^{19}$.

Brak twardych dowodów zarówno za, jak i przeciw autorstwu Rysińskiego omawianego poematu. Należy on do grupy rękopisów staropolskich, których atrybucję (według określenia Adama

17 Krzysztof Lanckoroński Włodzisławski h. Zadora (zm. 1591) - od 1545 r. dworzanin królewski, od 1551 r. łowczy sandomierski, kasztelan małogoski (1567-1589), radomski (1589-1591), jeden z pierwszych zwolenników reformacji w Małopolsce, fundator i patron zboru we Włodzisławiu; dwukrotnie żonaty: w 1566 r. z Anną Tęczyńską h. Topór (zm. 1581) i w 1582 r. z Zofią z Wzdowskich, wdową po Stanisławie Dunin Karwickim h. Łabędź, z którą doczekał się trzech synów i córki; por. A. Chudoba, Stanistaw Karwicki, PSB, 12, 1966-1967, s. 154; I. Kaniewska, Lanckoroński Wtodzistawski Krzysztof, PSB, 16, 1971, s. 443-445; Urzędnicy województwa sandomierskiego, s. 70 , s. 190.

18 K. Niesiecki, Herbarz, t. 9, s. 468: Zofia za Hieronimem Stano h. Gozdawa, wojskim sanockim (ibidem, t. 8, s. 495), szwagrem Stanisława Bala h. Gozdawa, podkomorzego sanockiego, z rodziny ewangelicko-reformowanej do XIX w., który pojął za żonę inną Wzdowską (vel Zdowska); ibidem, t. 2, s. 30. Hieronim był synem mieszczanina Stanisława Stano i Tyczyńskiej, przyjętym do herbu przez Balów w 1545 r., wiernym kalwinistą. Z małżeństwa ze Wzdowską miał kilka córek oraz syna Jerzego, posła na sejm w $1591 \mathrm{r}$.

19 K. Nizio, op. cit., s. 211. 
Karpińskiego) „można łatwo podważyć, ale nie da się jej obalić”20, a to dlatego, że ustalenie pewnej atrybucji dzieł anonimowych zachowanych $\mathrm{w}$ formie rękopiśmiennej jest niesłychanie trudne ${ }^{21}$, a zjawisko autorstwa zbiorowego występuje powszechnie. Do kolekcji Rysińskiego poemat mógł trafić niekoniecznie w okresie jego pobytu w Małopolsce i opieki nad Buczyńskimi ${ }^{22}$, lecz później - za pośrednictwem Stanisława Buczyńskiego, wieloletniego sekretarza hetmana litewskiego Krzysztofa II Radziwiłła, jego brata Jana ${ }^{23}$ lub Jana Bala, korespondenta i przyjaciela politycznego Radziwiłła z województwa ruskiego ${ }^{24}$. Wymiana tekstów publicystycznych między kalwinistami małopolskim i litewskimi ${ }^{25}$ wskazuje na duże prawdopodobieństwo krążenia w tym środowisku także utworów literackich i tworzenia kolekcji ich kopii. Mogły one następnie być wykorzystywane jako podarunki dla osób, które chciano w ten sposób pozyskać - naturalnie zmieniając dedykacje.

$\mathrm{Na}$ k. 1ver. rękopisu w lewym dolnym rogu figuruje niemal nieczytelna dopiska obcą ręką „Tho do ims. od dasz huc in kopy” („To do jejmości oddasz, hunc in kopii”; lekcja niepewna). Jeśli odczyt jest poprawny, wyjaśnia, dlaczego w papierach Rysińskiego nie zachował się oryginał poematu. Został on prawdopodobnie wysłany adresatce drugiej dedykacji, pominiętej przez Z. Celichowskiego, a wspomnianej przez K. Nizio („Je[j] Moscy moyey namylszy Pani Tre[m]beckÿ”,

20 A. Karpiński, Tekst staropolski. Studia i szkice o literaturze dawnej w rękopisach, Warszawa 2003 (Studia Staropolskie. Series Nova, t. 8/64), s. 21.

21 Por. ibidem, s. 63-114; M. Jarczyk, Prawo autorskie w odniesieniu do zbiorów specjalnych: refleksje badacza literatury dawnej, „Bibliotheca Nostra. Śląski Kwartalnik Naukowy”, 3, 2012, 3, s. 46-59.

22 Por. K. Nizio, op. cit., s. 211.

23 Por. K. Lepszy, Buczyński Jan, PSB, 3, 1937, s. 88-90. Autor biogramu błędnie twierdzi, że nie wiadomo, co się stało ze Stanisławem, a sekretarza Radziwiłła nazywa Janem.

$24 \mathrm{O}$ związkach Balów z ewangelicką linią Radziwiłłów zob. U. Augustyniak, Dwór i klientela Krzysztofa Radziwitta 1585-1640. Mechanizmy patronatu, Warszawa 2001, s. 205; T. Kempa, Wobec kontrreformacji. Protestanci i prawostawni w obronie swobód wyznaniowych $w$ Rzeczypospolitej $w$ końcu XVI $i$ w pierwszej potowie XVII wieku, Toruń 2007, s. 380-381, 389, 406-407.

$25 \mathrm{Na}$ przykład Uniżona prośba ewangelików do Króla JM i stanów Rzeczypospolitej na sejm walny roku MDCXXII nomine dissidentum z 1627 r. w uciskach ich pisana rozpowszechniana była w dwu wersjach, polskiej i litewskiej; zob. U. Augustyniak, Państwo świeckie czy księże? Spór o rolę duchowieństwa katolickiego w Rzeczypospolitej w czasach Zygmunta III Wazy. Wybór tekstów, Warszawa 2013, s. 367-402. 
k. 2ver. ${ }^{26}$. Chodzi zapewne o matkę (zm. przed 1609) Jana Jakuba Ryniewicza-Trembeckiego (1597-1678), brata polskiego (arianina), kaznodziei i poety ${ }^{27}$, syna Mikołaja Ryniewicza zw. Muchą, który zmienił nazwisko $\mathrm{w}$ obawie przed preskrypcją w latach czterdziestych XVII w. Potwierdza to jego przynależność (jak i syna Jakuba Teodora ${ }^{28}$ ) do środowiska arian związanych z Radziwiłłami birżańskimi. Natomiast dopiska „Miłoscy moyey Panu Bogu za to dziekuye moyey namylszy Panyi” w miejscu, gdzie Gospodarz zwraca się do Boga („Od ciebie jest lekarstwo na nasz stan tęskliwy”, k. 4ver.), wskazuje, że z jej adresatką łączył anonimowego komentatora silny związek emocjonalny i duchowy. Potwierdza to poważną pozycję kobiet w budowaniu wspólnoty duchowej w środowisku kalwinistów i braci polskich.

Przechodząc do omówienia Rozmów i pociech o stanie wdowim, należy zwrócić uwagę, że określenie ich przez pierwszego wydawcę „rozmowami” 29 jest uproszczeniem, choć rzeczywiście tekst został napisany w formie dialogu. Jego uczestnikami są owdowiały Gospodarz oraz Przyjaciel, który go odwiedza pod pretekstem załatwienia ważnego interesu, a w istocie $\mathrm{w}$ imieniu przyjaciół zaniepokojonych przedłużającą się samotnością Gospodarza i unikaniem przez niego powtórnego małżeństwa. Taka postawa odbiegała od przyjętej normy społecznej, choć było dopuszczalna w Konfesji sandomierskiej $^{30}$. Wbrew standardowym pochwałom małżeństwa, od początku tekstu zasygnalizowano wyższość świadomego wyboru samotności i wdowieństwa nad ponownym małżeństwem przy użyciu zróżnicowanych formalnie i logicznie argumentów zaczerpniętych z Biblii, a także anegdot i przysłów ${ }^{31}$, które urozmaicają dość monotonny wykład treści wyznaniowych.

26 K. Nizio, op. cit., s. 206.

27 Por. J. Tazbir, Ryniewicz (Reinovicius, Ryniowicz) Jakub, PSB, 33, 1991-1992, s. 541 .

28 Por. Bibliografia literatury polskiej „Nowy Korbut”, t. 3, s. 341-342.

29 Zob. Z. Celichowski, op. cit., s. 2-3.

30 Por. „Wyznawamy i to, że ci którzy dar ten od Pána Bogá mają, áby mogli bez żony żyć, tak żeby i w sercu, i w myśli czyści a powściągliwi byli, nie cirpiąc ná żądzach upalenia ciężkiego, takowi mogą Pánu Bogu w tymże powołaniu służyć, poki się będą znać tym darem obdarzonemi”, Konfesja Sandomierska, transkr. i koment. K. Długosz-Kurczabowa, Warszawa 1995, s. 230 (rozdz. 29 „O stanie bezmałżeństwa, i o stanie małżeńskim a o gospodarstwie”).

31 K. 10ver.: „Im dalej w las, tym więcej drzew”; k. 11 rec.: „Nie może się przeciwić glina garncarzowi”; k. 1ver.: „Iść leda dziurą”. 
Pojawienie się Przyjaciela opisuje Gospodarz (k. 4ver.), którego wynurzenia zajmują większość poematu ${ }^{32}$. W rzeczywistości mamy do czynienia z dialogiem pozornym, ponieważ Przyjaciel zabiera głos tylko dwukrotnie, na początku i na końcu narracji, bezdyskusyjnie uznając słuszność racji „najmilszego brata” (k. 12rec.). Już na wstępie Gospodarz nie dopuszcza gościa do głosu, proponując mu, w czasie oczekiwania na zwyczajowy poczęstunek, wysłuchanie przygotowanego przez siebie zestawienia przykładów biblijnych dowodzących szczególnej opieki boskiej nad wdowami i sierotami. Używa też jeszcze jednego argumentu: „Wszakże jednak nie tęskni, lepiej ci to wiedzieć, Aniżeli próżnując darmo czas przesiedzieć” (k. Gver.)

Propozycja rozmowy na ważny temat zamiast próżnej gadaniny wydaje się charakterystyczna dla obyczajowości środowiska określanego dotąd ogólnikowo jako „krąg kalwinów [sic!] małopolskich”33. Treści wyznaniowe poematu zasygnalizowała już K. Nizio, ale wymagają one głębszej analizy w celu odtworzenia tożsamości i specyfiki środowiska, w którym powstał. Określenie „dydaktyczny i moralizatorskie” nie oddaje charakteru całego utworu, ponieważ składa się on (jak już wspomniano) z kilku części, niekoniecznie wspólnego autorstwa. Różnią się one zarówno stylem, jak charakterem. Cechy moralitetu ma przede wszystkim poemat Rozmowy i pociechy o stanie wdowim. Natomiast poprzedzająca go Do pobożnych sierot przemowa (k. 3ver.) odnosi się do ówczesnych realiów obyczajowych i przedstawia stan wdowi taki, jaki był, a nie jaki być powinien.

Wbrew twierdzeniu K. Nizio omawiany utwór nie jest jedynie „kolejną wersją, występujących często w literaturze staropolskiej, rozważań na temat świętości małżeństwa" 34 . Nakreślony w nim obraz wdowieństwa „tęskliwego” - samotnego, przykrego, obarczonego poczuciem zbliżającej się śmierci - dotyczy obu płci i podważa stereotypowe poglądy na relacje między nimi w epoce staropolskiej. Dotyczy to przede wszystkim utrwalonej w starszej historiografii opinii o kobietach jako grupie pokrzywdzonej przez staropolski system patriarchalny, a raczej patrymonialny ${ }^{35}$. System ten regulował stosunki

32 Około siedem na dwanaście stron (k. 4, 5, 6ver.-k. 11ver.).

33 Por. K. Nizio, op. cit., s. 211.

34 Por. ibidem, s. 207.

35 Teza M. Boguckiej, prezentowana w licznych jej publikacjach, przede wszystkim w książkach: Biatogtowa $w$ dawnej Polsce. Kobieta $w$ spoteczeństwie polskim XVI-XVIII wieku na tle porównawczym, Warszawa 1998 oraz Mizoginia, Warszawa 2018. 
rodzinne w całej wczesnonowożytnej Europie, w której żonaty mężczyzna - żywiciel i obrońca rodziny - występował w stosunku do dzieci i żony jako odpowiednik rzymskiego pater familias. Rzeczpospolita nie była pod tym względem wyjątkiem, nie ma jednak podstaw, by staropolski patriarchat uznawać za bardziej represyjny niż w innych krajach. Nie ulega wątpliwości, że w systemie tym kobiety były grupą podporządkowaną, nie musiało to jednak automatycznie oznaczać upośledzenia.

Status prawny i majątkowy kobiet wszystkich stanów regulowały w nowożytnej Rzeczypospolitej przepisy prawa świeckiego (miejskiego: magdeburskiego lub chełmińskiego i ziemskiego) oraz prawo kościelne, w zależności od wyznania. Generalną zasadą było, że pozostawały one przez całe życie pod opieką rodziców lub męża. W prawie ziemskim opieka nad kobietami (zwłaszcza wdowami) miała znaczenie przede wszystkim w dwóch wypadkach: przy dysponowaniu dobrami nieruchomymi i przy zastępstwie sądowym. Kuratorów dla wdów ustanawiano analogicznie jak dla nieletnich, w pierwszym rzędzie należało uwzględnić najbliższych krewnych. Choć wszystkie poczynania wdów były przez nich kontrolowane, co zapewne niejednokrotnie prowadziło do ich ubezwłasnowolnienia i grabieży ich majątku, brak wystarczających przesłanek, aby generalizować takie przypadki. Zdarzało się, że kobieta sama sobie wybierała kuratora, niewłaściwie zaś wykonujący swoje obowiązki mógł zostać na jej żądanie usunięty.

Faktyczną sytuację wdów określały zapisy intercyzy ślubnej dotyczące kwestii ich zabezpieczenia materialnego: posagu, wyprawy, wiana, przywianku, a szczególnie dożywocia - wzajemnej umowy między małżonkami, dającej prawo do użytkowania ich dóbr dziedzicznych do końca życia pod warunkiem, że owdowiała strona nie zawrze kolejnego małżeństwa. W praktyce oznaczało to, że w chwili śmierci męża kobieta, dopóki pozostawała w stanie wdowim, miała prawo do dożywotniego dysponowania jego wszystkimi dobrami, w tym także nieruchomościami. Wdowa mogła zarządzać dobrami zupełnie samodzielnie ${ }^{36}$.

Sytuacja życiowa staropolskich białogłów była zróżnicowana i zależała od ich: wieku, pozycji społecznej, przynależności stanowej, osobowości. Należy wziąć pod uwagę, że wdowy mogły być w sytuacji relatywnie

36 Por. P. Dąbkowski, Prawo prywatne polskie, t. 1, Lwów 1910, s. 528-530. Za konsultację prawniczą w kwestii faktycznego statusu wdów dziękuję dr. Łukaszowi Gołaszewskiemu. 
lepszej niż owdowiali mężczyźni, obarczeni nieletnim potomstwem i zmuszeni do powtórnego małżeństwa ze względu na konieczność szybkiego znalezienia dla niego opiekunki, a zarazem zarządczyni całego kobiecego gospodarstwa domowego. W jeszcze gorszej sytuacji znajdowali się wdowcy w podeszłym wieku, decydujący się na ponowny związek nie tyle z potrzeby zaspokojenia popędu seksualnego, ile w nadziei uzyskania opieki na starość. Nadzieje te często okazywały się złudne. W księgach sądowych i testamentach znajdujemy drastyczne opisy znęcania się młodych żon nad starcami (zwykle przy pomocy służących), począwszy od głodzenia i bicia aż do prób uśmiercenia ${ }^{37}$.

Słusznie zatem Gospodarz sceptycznie ocenia szanse na szczęśliwe małżeństwo starzejącego się mężczyzny, wbrew bowiem nakazom boskim, by starsze wdowy zajmowały się pobożnym zarządem domów, a młode powtórnie wychodziły za mąż i płodziły dzieci, dzieje się odwrotnie. Młode wdowy nie chcą iść za mąż, natomiast starsze starają się jak najprędzej znaleźć sobie młodego męża („podgoleńca”), odtrącając „człowieka statecznego” (k. 3ver.). Odpowiada to realiom epoki, w której zamożne wdowy mogły samodzielnie podejmować decyzje o wyborze drugiego męża jako „panie sobie wolne"38. Według ostatnich ustaleń badacza demografii historycznej, „część owdowiałych kobiet nie wychodziła ponownie za mąż i mniej więcej od 40. roku życia w szlacheckiej populacji kobiet rósł udział pań stojących na czele gospodarstw domowych" ${ }^{39}$. W środowisku ewangelickim wiele $\mathrm{z}$ nich doskonale zarządzało dożywotnio administrowanym majątkiem, wyręczając się w sprawach prawnych zaufanymi ekonomami ${ }^{40}$. Jednocześnie synody wnikliwie i arbitralnie

37 Przykładem może być wstrząsająca skarga starego męża na młodą żonę w testamencie Jana z Oporowa Ostrowskiego, wojskiego kruszwickiego, z 8 X 1654 r.: „z rąk moich odebrawszy gospodarstwo, głodem mnie morzą, wodę pić muszę, a co większa brzydzą się mną małżonkiem i starością moją. Innych sobie osób do lubości cielesnej zażywa, z nimi obcuje, co wszystkiemu światu wiadomo, a nawet i z czeladz(i)ą moją własną", Testamenty szlacheckie z ksiag grodzkich wielkopolskich z lat 1657-1680, t. 2, wyd. P. Klint, Wrocław 2011, s. 45-46.

38 Więcej zob. U. Augustyniak, Pozycja kobiet na ewangelickich dworach magnackich i szlacheckich $w$ Wielkim Księstwie Litewskim w 1. pot. XVII w. na przyktadzie Radziwittów birżanskich i ich klienteli, w: Dwór kobiecy w Rzeczypospolitej XVII i XVIII wieku, red. B. Popiołek, A. Penkała-Jastrzębska, K. Pyzel, Kraków 2021, s. 15-32.

39 P. Guzowski, Rodzina szlachecka $w$ Polsce przedrozbiorowej. Studium demograficzne, Białystok 2019, s. 188-189 (cyt. ze s. 188).

40 Zob. G. Perczyńska, Kobiety Iszkotci, czyli dzieje zarządzania majętnościa, $\mathrm{w}$ : Administracja i życie codzienne $w$ dobrach Radziwittów XVI-XVIII wiek, red. 
ingerowały w pożycie małżeńskie swoich członków, a ich swoboda obyczajowa była ściśle ograniczona. Za zawieranie małżeństw bez uprzedniej zgody starszych zborowych lub porzucenie żony groziła klątwa ${ }^{41}$ lub ekskomunika, która mogła trwać kilkadziesiąt lat, nawet po pogodzeniu się małżonków ${ }^{42}$. Co więcej, sądząc z akt synodów małopolskich, częściej i ostrzej karano mężczyzn, zwłaszcza katechistów i duchownych ${ }^{43}$, jako bardziej odpowiedzialnych. Kobiety za obrażanie męża i nierządne życie traktowano łagodniej ze względu na ich „przyrodzoną słabość”, jednak w wypadku recydywy groziła im kara śmierci ${ }^{44}$.

Reasumując, wizerunek niewiast w Rozmowach $i$ pociechach o stanie wdowim odbiega od utartych schematów. Przede wszystkim, wbrew deklaracjom Gospodarza żalu i osamotnienia po śmierci żony, zastanawiające jest, że jej postać pojawia się pojawia się tylko raz i jest scharakteryzowana bardzo ogólnikowo (k. 5ver.):

Wedle Boga roztropna, wedle świata baczna,

Cnotliwa, zacna, piękna, pomoc po niej znaczna ${ }^{45}$.

U. Augustyniak, Warszawa 2009 (Fasciculi Historici Novi, t. 9), Warszawa 2009, s. 7-109; por. testament Katarzyny z Oborskich Grabowskiej, stolnikowej witebskiej (Proszczyca, 9 III 1727) wraz z suplementami, w: Testamenty ewangelików reformowanych $w$ Wielkim Księstwie Litewskim $w$ XVI-XVIII wieku, red. U. Augustyniak, Warszawa 2014, s. 249-274.

41 Akta synodów różnowierczych w Polsce, t. 3: Matopolska, oprac. M. Sipayłł, Warszawa 1983, s. 184 (41: Synod dystryktowy w Bełżycach, 15 X 1596).

42 Świadczy o tym przypadek Przecława Bobrownickiego, obłożonego ekskomuniką po oskarżeniu żony za odmowę mieszkania z nią w 1610 r. (ibidem, s. 301: 117 [synod we Włoszczowej 5 II 1610, p. 6]), a uwolnionego od niej, mimo licznych odwołań od decyzji „starszych” synodu i poparcia żony, w $1621 \mathrm{r}$. (ibidem, s. 424 [190: synod dystryktowy w Krzcięcicach, dopiero w 1624 r.]; s. 449 [204: synod dystryktowy w Okszy 2 VII 1623, p. 3]).

43 Ibidem, s. 30 (123: Konstytucja dystryktowa w Okszy 20 X 1610, p. 2: sprawa ks. Jana Olińskiego).

44 Ibidem, s. 316 (317: synod w Lublinie 11 VI 1611, p. 10): sprawa żony ks. Mikołaja Orlicza, skazanej za „nieprzystojne życie w stanie małżeńskim” na publiczne przeproszenie członków zboru na synodzie, złożenie przysięgi o „zachowaniu zdrowia męża” (!), chodzenie do końca życia w czerni, zakaz przechadzek bez męża, zaprzestanie schadzek z podejrzanymi osobami i noszenie do końca życia na szyi „pamiątki” upadku swego. W razie złamania przysięgi groziła jej jednak kara śmierci bez procesu.

45 Dystych nawiązujący do rozpowszechnionej w całej Europie łacińskiej sentencji aliteracyjnej wyliczającej pięć przymiotów kobiety: pia, prudens, pulchra, pudica, potens; por. R. Grześkowiak, op. cit., s. 144, 146. 
Jako osoba piękna, a zarazem skromna, stanowiąca podporę dla męża i zapewniająca dobre ćwiczenie dziatek w pobożności, zmarła stanowi archetyp chrześcijańskiej matrony, wokół której skupia się życie rodzinne. $\mathrm{Z}$ jej apologią kontrastuje satyryczny wizerunek wdów - począwszy od Do pobożnych sierot przemowy (k. 3ver.) aż do karykaturalnego przedstawienia w poemacie starej kobiety, przywykłej do ciągłego zaglądania do zwierciadła, która ma pretensje do jego wytwórców o widoczne pogorszenie się swego wyglądu (k. 11 rec. $)^{46}$.

Ciekawe, że niejednoznaczna jest też prezentacja postaci kobiecych uznawanych za wzory do naśladowania zaczerpnięte z Biblii. Dominuje wprawdzie ich wizerunek jako osób słabych, upośledzonych przez los i zdanych na boską i na męską opiekę, stworzony na podstawie przykładów postaci biblijnych: Rut (k. 7rec.-9ver.), wdów z Sarepty (k. 6ver.-7rec.) i matki młodzieńca z Nain (k. 10rec.) oraz Sary, córki Fanuela (k. 9ver.) z Księgi Tobiasza. Z drugiej jednak strony przywołano postacie kobiet silnych i aktywnych, jak prorokini Anna (k. 9ver.), a przede wszystkim Judyta o sercu „rzadkim w niewieście” (k. 9ver.) - postać popularna w epoce renesansu, w moralistyce traktowana jako żeński odpowiednik Dawida, który pokonał silniejszego Goliata. Autor, co warto podkreślić, wzorców osobowych wdów szukał w księgach apokryficznych, nieuznawanych w kanonie ewangelicko-reformowanym, pomijając przykłady wdów z odnotowanych w Ewangelii św. Łukasza przypowieści o sędzi i natrętnej wdowie, która wymusiła na nim korzystny dla siebie wyrok przez nieustanne nagabywanie (18, 3-5), krytyki Jezusa nauczycieli pisma, którzy „objadają domy wdów” $(20,47)$ oraz opowiadania o wdowim groszu $(21,2-3)$.

Przytoczone przykłady biblijnych postaci kobiecych to jedynie pretekst do zilustrowania wzorców męskiej opieki nad nimi, gdyż interlokutorami są mężczyźni, a Gospodarz może być uznany za alter ego autora lub jego zleceniodawcy. Jego prezentacja koncentruje się na sytuacji życiowej wdowca, który nie chce - wbrew naciskom otoczenia - zawrzeć powtórnego małżeństwa. Swoją postawę uzasadnia argumentami czerpanymi z lektury Pisma Świętego i obserwacji obyczajów współczesnych kobiet. Wyjaśnienie, że „przychyliwszy serce” do pierwszego małżeństwa (k. 11ver.), z zawarciem powtórnego czeka na

46 Postać starej kobiety („baby”) była często przedmiotem szyderstw w literaturze staropolskiej; zob. M. Bogucka, Starość w twórczości pisarzy polskiego renesansu i baroku, „Kwartalnik Historii Kultury Materialnej”, 58, 2010, 1, s. 61-70. 
znak boży oraz świadomy wybór życia w odosobnieniu nie przystają do ówczesnej praktyki społecznej. Dominującą cechą charakterystyki Gospodarza jest jednak żarliwa pobożność, a głównymi tematami rozważań są kwestie religijne i przygotowanie do śmierci.

Oba wątki narracji wzajemnie się uzupełniają. Godny podkreślenia jest wysoki poziom samoświadomości i introspekcji Gospodarza, analizującego nie tylko swoje relacje z Bogiem, lecz i własne uczucia po śmierci żony. Jego wizerunek jest silnie nacechowany emocjonalnie, odwołuje się do miłości Boga do człowieka oraz sympatii i współczucia między ludźmi ${ }^{47}$. Od początku poematu (k. 5ver.) do jego końcowej części (k. 10ver.-12ver.) wyraża typowe dla ewangelickich moralistów przekonanie, że nieszczęścia spadające na człowieka wynikają z jego „złości”, a nie z mściwości Boga, którego celem jest zawsze naprowadzenie wiernego na właściwą ścieżkę postępowania. Stosowana przez autora frazeologia, służąca wzbudzeniu współczucia czytelników dla „stanu wdowiego” przez stosowanie zdrobnień ${ }^{48}$, jest zbieżna z językiem Biblii brzeskiej, w której zdrobnienie „sierotki”, niewystępujące w katolickich tłumaczeniach Pisma Świętego, podkreśla czułość i troskę Boga o kobiety i dzieci, upośledzone społecznie poprzez pozbawienie ich rodzicielskiej lub mężowskiej opieki:

Wszakeś ty jest jednaki on Bóg starodawny

Wszelakiego sieroctwa opiekalnik sławny

W tym się opowiedając od pierwszego wieka

Że jako zrzrenicę swej, ty strzeżesz człowieka

Sieroctwem skaranego, który się do Ciebie

Ucieka sprawą, wiarą, przeto siedzisz w niebie.

Abyś z góry swej świętej doległości nasze

Widział, które wszech sierot dolegają zawsze (k. 4ver.) ${ }^{49}$.

Oczekiwanie od Boga czułości i przyznanie się do przejawów żalu, jak płacz i wzdychanie oraz bezsenność (k. 10ver.), nie przystają do standardowych wyobrażeń o wzorcach męskości w kulturze staropolskiej, mimo że są zgodne z obowiązującą w niej konwencją

47 Słowa „miłość”, „miły” pojawiają się w tekście 11 razy. W pierwszym znaczeniu w zwrotach: „wszechmocny Pan / Opatruje sieroty, miłuje wdowi stan” (k. 3ver.); (wdowa z Sarepty) „Miłości, łask u Boga wnet się okazała (k. 7rec.); w drugim znaczeniu w słowach Booza kierowanych do Rut: „Słuchaj miła córko” (k. 8rec.).

$48 \mathrm{Na}$ przykład „dziateczki”, „sierotki”, „niebożąteczko”, „chudzineczka”, „białogłówka” etc.

49 Biblia brzeska 1563, wyd. P. Królikowski, Kraków 2003, Wtóre Księgi Mojżeszowe 22, 24; Piąte Księgi Mojżeszowe 10, 18. 
eksponowania emocji w życiu publicznym ${ }^{50}$. Natomiast zawarte $\mathrm{w}$ omawianym poemacie wynurzenia osobiste autora na temat jego prywatnej pobożności i zachowań w obliczu nieszczęścia pozwalają uznać go za przykład ewangelickiej literatury intymistycznej. Podczas gdy w nowszej literaturze anglosaskiej sytuacja ojców opłakujących zmarłe dzieci stanowi odrębny przedmiot badań interdyscyplinarnych, w historiografii polskiej poświęcono jej dotąd niewiele uwagi ${ }^{51}$. Zagadnienie żalu wdowca po śmierci żony nie budzi zainteresowania badaczy, choć może być przydatne w badaniach realiów stosunków rodzinnych w nowożytnej Rzeczypospolitej. Omawiany poemat stanowi, naszym zdaniem, przykład źródła do badania tego problemu. Autor stara się wykazać, że śmierć żony w połogu, przypadek nader częsty w tej epoce, może stanowić przełom w życiu człowieka, uświadomić mu marność doczesnego dostatku oraz skłonić do nawrócenia ku Bogu i całkowitego Mu zaufania, mimo kolejnych strat osobistych i majątkowych (k. 5ver.):

Krótko mówiąc, dla żaliu prze jej święte cnoty

Prawiem miał za żywota tu przy niej wiek złoty.

A toż w tem słusznem żaliu, widzę złości moje

Prze które tak cną żonę, i z nią dziatek dwoje

Bóg odjął w oczach moich, z żalem mem serdecznym.

A cóż rzec, musi człowiek za dekretem wiecznym.

A mniejszych nie wspominam przygód co bywały:

Dom kosztowny pogorzał, bydła wyzdychały.

Tego roku też widzisz co mi się zaś zstało

Zboża wszytki grad potłukł, że nic nie zostało ${ }^{52}$.

A ja nędznik co mówię? Przedsię, o mój Panie,

Choćbyś mię też i zabił, w tobie me ufanie.

${ }^{50}$ Odwoływanie się do emocji było stałym elementem staropolskiej polityki, a widoczne wzruszenie mówcy sejmowego miało pozyskać poparcie słuchaczy dla jego wywodów, np. w ocenie autora relacji z sejmu konwokacyjnego 1587 r., który uznał udany płacz arcybiskupa gnieźnieńskiego (Stanisława Karnkowskiego) za dowód jego umiejętności manipulacji odbiorcami: „Interim udał się IMci X. Arcybiskupowi płacz, że też samego wojewodę płockiego Grzegorza Zielińskiego) [--] poruszył", Dyjaryjusze sejmowe 1587 r.: sejmy konwokacyjny i elekcyjny, wyd. A. Sokołowski, Kraków, s. 13. Szerzej na ten temat zob. U. Augustyniak, Racje i emocje w staropolskiej polityce, „Przegląd Humanistyczny”, 1, 1979, s. 57-68.

51 Najważniejsze opracowania wymienia D. Guzowska, Ojciec purytanin. Ekspresja ojcowskich emocji w angielskich źródtach autobiograficznych epoki Stuartów, Warszawa 2020, s. 8 , przyp. 6 i s. 9, przyp. 7 .

52 Nawiązanie do nieszczęść, które spotkały Hioba, zob. Biblia brzeska 1563, Księgi Hiobowe 1, 21-22. 
Gospodarz wielokrotnie (k. 5rec., 9ver., 10rec.) deklaruje bezwzględne poddanie się woli Bożej (k. 10rec.-10ver.):

Spuściłem się na Boga, tam wytrzeszczam oczy [--]

Wżdyć kiedy z łaski swojej sam to zdarzyć raczy

Że mnie i dziatek moich jeszcze nie przebaczy.

[--] Pewienem, iże on mnie i moje dziateczki

Dawno naterminował w swe boskie książeczki,

Z których w swojej naświętszej a boskiej dobroci

Ku mnie i dziatkom moim pamięć swą obróci.

Przekonanie, że: „Tak ci, kto Bogu ufa, nigdy nie utracił” (k. 9ver.), a przedwieczne dekrety Stwórcy są niepodważalne (k. 5rec., 9ver., 10rec.) można interpretować jako świadectwo wierności autora kalwińskiej doktrynie predestynacji ${ }^{3}$. Warto jednak zauważyć, że odpowiada ono wzorcowej postawie każdego chrześcijanina, który powinien bez szemrania stawić czoło spadającym na niego $\mathrm{z}$ woli boskiej klęskom materialnym i nieszczęściom osobistym, traktując je jako karę za grzechy, a zarazem doświadczenie pozwalające człowiekowi stawać się lepszym w biedzie niż w dostatku (k. Grec.). Treści wyznaniowe Stanu wdowiego mogli zaakceptować wszyscy ci, których przewodnikiem miał być „krzyż złoty” (k. 3rec. „Na herb Śreniawę”) - zarówno kalwiniści, jak bracia polscy ${ }^{54}$. Wskazuje na to także wtórna dedykacja utworu ariance Trembeckiej.

Na ponadwyznaniowe przesłanie poematu wskazuje także zamieszczony na jego zakończenie psalm (k. 12ver.):

Pan jest stróżem przychodniowi,

Pan sierotę i stan wdowi

Ma na pieczy. Tenże gładzi

Co zły w głowie swej uradzi ${ }^{55}$.

Rzuca to światło na stosunki w środowisku akatolików małopolskich na przełomie XVI i XVII w. Wspomniano już, że ród Wzdowskich przetrwał tylko w linii żeńskiej, a jego przedstawicielki

53 Konfesja Sandomierska, s. 75-81 (rozdz. 10 „O przejrzeniu Bożym i o wybieraniu świętych do niego").

54 Por. K. Nizio, op. cit., s. 208.

55 Jest to cytat z tłumaczenia Psalmu 146 Jana Kochanowskiego i stanowi kolejny dowód nad ponadkonfesyjne funkcjonowanie Psatterza Dawidów; zob. J. Pelc, Tradycja Jana Kochanowskiego w kulturze i literaturze polskiej (XVI-potowa VIII w.), Warszawa 1965. Za wskazanie źródła cytatu dziękuję prof. Marii Barłowskiej. 
wychodziły za mąż z reguły za kalwinistów. $\mathrm{O}$ wyznaniu męża adresatki dedykacji utworu, kasztelana połanieckiego Niedrwickiego, brak informacji - prawdopodobnie był kalwinistą, ale mógł być także bratem polskim, bowiem dwu mężów innej, nieznanej z imienia Wzdowskiej - Jakuba (poprawnie Stanisława) Karwickiego herbu Łabędź z województwa sandomierskiego, dworzanina królewskiego i starostę latowickiego w latach $1609-1618^{56}$ oraz Krzysztofa Lanckorońskiego - nazywa Kasper Niesiecki „arianami”57, choć w rzeczywistości byli aktywnymi uczestnikami synodów Jednoty Małopolskiej ${ }^{58}$. Pomyłka jezuity mogła wyniknąć nie tylko z jego braku orientacji w różnicach między „,heretykami”, lecz i z trudności jednoznacznego określenia tożsamości wyznaniowej konkretnych osób w środowisku małopolskich różnowierców w końcu XVI stulecia. Na podstawie analizy poematu oraz akt synodów małopolskich $\mathrm{z}$ omawianego okresu można postawić hipotezę, że nawet po odłączeniu się zboru braci polskich od kalwinistów w 1562 r. utrzymywano wzajemne kontakty prywatne i rodzinne.

Większość wywodu Gospodarza poświęcona jest jednak nie stosunkom z ludźmi, lecz relacjom z Bogiem, którego przywołano w tekście 27 razy jako Boga jedynego, „starodawnego” (k. 4ver.), „wszechmogącego, mocnego i straszliwego” (k. 6ver.), „wiecznie żywego” (k. 8rec., 10rec.), odpowiadającego wizerunkowi Jahwe ze Starego Testamentu, podczas gdy „Pan Jezus Chrystus, syn jego prawdziwy” (k. 10rec.) występuje tylko czterokrotnie. Anonimowy autor poematu podkreśla szczególną opiekę Boga nad ubogimi, sierotami i wdowami (k. 10rec.), i miłosierdzie boskie w stosunku do grzesznych ludzi występujące zarówno w Starym, jak w Nowym Testamencie, gdzie ewangelista Łukasz przypisuje Chrystusowi rahamin, czyli „współczucie równe miłości matczynej, wykraczające poza ludzką solidarność z potrzebującymi, oznaczające gotowość Boga do ratowania człowieka w każdej sytuacji materialnej czy duchowej zagrażającej jego

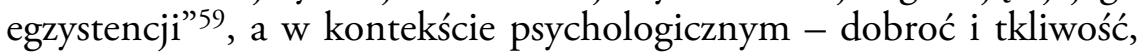

56 Por. K. Niesiecki, op. cit., t. 5, s. 51.

57 Por. ibidem, t. 9, s. 468.

58 Stanisław Dunin Karwicki starosta latowicki (Akta synodów, t. 3, s. 207, 224, 234-236, 238, 315); Hieronim Lanckoroński [Lanckoruński] h. Zadora (zm. 1605-1609), łowczy sandomierski (1572), właściciel Włodzisławia w latach 1596-1609 (ibidem, s. 182, 186, 210, 244, 299).

59 P. Podeszwa, „Obroń mnie przed moim przeciwnikiem” (Ek 18, 3). Status wdowy w Opus Lucanum, „Biblica et Patristica Thoruniensia”, 8, 2005, 2, s. 81-100. 
cierpliwość i wyrozumiałość, czyli gotowość do przebaczenia. Takie pojmowanie relacji z Bogiem przejawia się w oczekiwaniu od niego nie tylko rzeczowej pomocy, ale „przytulenia” (domyślnie „do swego łona”, k. 10ver.).

Męskim wzorcem osobowym jest Gedeon, którego imię pojawia się jednak nie w tekście głównym, lecz w dopiskach siedemnastowiecznego komentatora na marginaliach (k. 10 rec., 11 rec. $^{60}$ ), pomijanych $\mathrm{w}$ dotychczasowych opracowaniach lub błędnie interpretowanych ${ }^{61}$. W moralistyce protestanckiej postać ta jest metaforą człowieka gotowego wykonać wszystko, czego Bóg od niego zażądał. Jego głównymi cechami były wiara, posłuszeństwo i pokora oraz „duch męskiej stałości” (k. 10ver.), o którą Gospodarz prosi Boga. Tę cechę można interpretować jako odpowiednik hebrajskiego hessed - wierności sobie wbrew przeciwnościom, stanowiącej sprawdzian wytrwałości w wierze $^{62}$. W wypadku owdowiałego Gospodarza jest to także cecha niezbędna do wychowania potomstwa w duchu pobożności (k. 5ver.). Autor poematu nawiązuje tu do problemu miłości ojcowskiej, obecnego w literaturze nowożytnej Europy - także polskiej - zarówno w środowiskach różnowierczych, jak katolickich ${ }^{63}$.

Warto także zwrócić uwagę na wzmiankę o księgach Pisma Świętego, które „leżą na stole” i służą do nauczania syna Gospodarza (k. Grec.). Ta informacja także odpowiada realiom epoki. Jak zauważyła Izabela Winiarska-Górska:

Z szesnastego stulecia pochodzą udokumentowane w synodaliach różnowierczych głosy mówiące o konieczności nowej edycji polskiej Biblii w poręcznym formacie i w przyjaznym dla oka, zwłaszcza dla ludzi w podeszłym wieku, kształcie liter, co pozwala wnosić, że wśród ewangelików reformowanych, podobnie jak u braci polskich, z pewnością istniał zwyczaj indywidualnej lektury ${ }^{64}$.

$60 \mathrm{Na}$ marginesie k. 10rec. dopisek majuskułą: „GEDEONIS frater” (pobratymiec Gedeona, postaci biblijnej opisanej w Sdz 6-8); na marginesie k. 11 rec. dopisek „Pomano moią Gedeonie” (lekcja niepewna).

61 Por. K. Nizio, op. cit., s. 206, przyp. 9 - o Gedeonie Bałabanie, biskupie halickim (sic!).

62 Por. P. Podeszwa, op. cit., s. 89.

63 Zob. D. Guzowska, op. cit.; Ojcowskie synom przestrogi. Instrukcje rodzicielskie (XVI-XVII w.), wstęp i objaśnienia D. Żołądź-Strzelczyk, M. E. Kowalczyk, Wrocław 2017.

64 I. Winiarska-Górska, Szesnastowieczne przektady Pisma Świętego na język polski 1551-1599 jako gatunek nowożytnej książki formacyjnej, Warszawa 2017, s. 84. 
Spostrzeżenie to można zastosować także do poradników życia chrześcijańskiego - takich jak omówiony utwór. Kopia Stanu wdowiego, wykaligrafowana starannym renesansowym duktem, była niewątpliwie jedną $\mathrm{z}$ wielu krążących $\mathrm{w}$ środowisku szlacheckim, przeznaczonych do rozpowszechniania poprzez czytanie osobom niepiśmiennym, np. żonie Przyjaciela (k. 12rec.), lub przesyłania znajomym do samodzielnej lektury. $Z$ analizy treści poematu wynika, że właśnie $\mathrm{w}$ celu przekazywania między ludzi miał on być przepisany „na osobnej karcie” (k. 12ver.). Należał zatem do rodzaju wierszy gromadzonych w kolekcjach użytkowych o określonej tematyce ${ }^{65}$, wykraczającej poza uroczystości rodzinne, w których specjalizowała się „muza domowa”"66, a jego kopie mogły docierać do kalwinistów i braci polskich zarówno w Małopolsce, jak w Wielkim Księstwie Litewskim. Problem męskiego wdowieństwa poruszony w utworze był prawdopodobnie przedmiotem szerszej refleksji w środowisku różnowierczym tak ze względów wyznaniowych, jak społecznych. Badania tego zagadnienia mogą być przydatne do wyjścia poza stereotypowe definiowanie znaczenia „płci kulturowej” i „kategorii męskości” w epoce staropolskiej.

\section{Bibliografia}

Źródła i wydawnictwa informacyjne

Biblia Brzeska 1563, wyd. P. Królikowski, Kraków 2003

Bibliografia literatury polskiej „Nowy Korbut”, t. 3, red. K. Budzyk, Warszawa 1963

Estreicher K., Bibliografia polska XIX stulecia lata 1881-1900, t. 1-4, Kraków 1906-1916

Herby rycerstwa polskiego Bartosza Paprockiego zebrane i wydane r. p. 1584, wyd. J. K. Turowski, Warszawa 1874, reprint: Warszawa 1988

Katalog rękopisów staropolskich Biblioteki Kórnickiej XVI-XVIII w., t. 5: Literaria, oprac. A. Mężyński, Kórnik 1992

Księga wpisów kanclerza Jana Zamoyskiego MK 133 z Archiwum Gtównego Akt Dawnych $w$ Warszawie lata 1587-1595, wyd. W. Krawczuk, Kraków 2001 (Sumariusz Metryki Koronnej. Seria Nowa, t. 2)

Niesiecki K., Herbarz Polski, wyd. J. N. Bobrowicz, Warszawa 1989

${ }^{65}$ Por. A. Karpiński, op. cit., s. 71.

${ }^{66}$ Zob. L. Ślęk, Muza domowa: okolicznościowa poezja rodzinna czasów renesansu i baroku, Wroctaw 1991 (Acta Universitatis Wratislaviensis, t. 810), passim. 
Stanu wdowiego tęskliwego pobożne zabawy i pociechy, z rękopisu Biblioteki Kórnickiej wyd. Z. Celichowski, Poznań 1891

Testamenty szlacheckie z ksiag grodzkich wielkopolskich z lat 1657-1680, t. 2, wyd. P. Klint, Wrocław 2011

Urzędnicy województwa sandomierskiego XVI-XVIII wieku. Spisy, oprac. K. Chłapowski, A. Falniowska-Gradowska, red. A. Gąsiorowski, Kórnik 1993

VL, t. 1, Petersburg 1859

Żychliński T., Ztota księga szlachty polskiej, t. 1-31, Poznań 1879-1908

\section{Opracowania}

Augustyniak U., Dwór i klientela Krzysztofa Radziwitta 1585-1640. Mechanizmy patronatu, Warszawa 2001

Bogucka M., Biatogtowa $w$ dawnej Polsce. Kobieta w spoteczeństwie polskim XVI-XVIII wieku na tle porównawczym, Warszawa 1998

Bogucka M., Mizoginia, Warszawa 2018

Bogucka M., Starość w twórczości pisarzy polskiego renesansu i baroku, „Kwartalnik Historii Kultury Materialnej”, 58, 2010, 1, s. 61-70

Dąbkowski P., Prawo prywatne polskie, t. 1, Lwów 1910

Grześkowiak R., „Próżno się kusić, czym nie dano być”. Jak Salomon Rysinski pasowat Biernata z Lublina na pierwszego paremiologa Rzeczypospolitej, $\mathrm{w}$ : Biernat z Lublina a literatura $i$ kultura wczesnego renesansu $w$ Polsce, wyd. J. Dąbkowska-Kujko, A. Nowicka-Struska, Lublin 2015, s. 123-153

Guzowska D., Ojciec purytanin. Ekspresja ojcowskich emocji w angielskich źódtach autobiograficznych epoki Stuartów, Warszawa 2020

Guzowski P., Rodzina szlachecka $w$ Polsce przedrozbiorowej. Studium demograficzne, Białystok 2019

Jarczyk M., Prawo autorskie w odniesieniu do zbiorów specjalnych. Refleksje badacza literatury dawnej, „Bibliotheca Nostra. Śląski Kwartalnik Naukowy", 3, 2012, 3, s. 46-59

Kaniewska I., Lanckoroński Wtodzistawski Krzysztof, PSB, 16, 1971, s. 443-445

Karpiński A., Tekst staropolski. Studia i szkice o literaturze dawnej $w$ rękopisach, Warszawa 2003 (Studia Staropolskie. Series Nova, t. 8/64)

Kempa T., Wobec kontrreformacji. Protestanci i prawostawni w obronie swobód wyznaniowych $w$ Rzeczypospolitej $w$ końcu XVI i w pierwszej potowie XVII wieku, Torun 2007

Korotyński W., Salomon Rysinski. Studjum, wyd. A. H. Kirkor, Wilno 1863

Latyshonak A., Navukova krynitsy samakreslennya Salamona Rysinskaga jaka Biatorus', w: idem, Repharmacy and gramadstva: XVI stagoddze. Materyaly International navukai kanferentsi, Mieńsk 2005

Lulewicz H., Rysiński Salomon, PSB, 33, 1991-1992, s. 553-557

Mańkowski T., Hoczew i Balowie, „Miesięcznik Heraldyczny. Organ Towarzystwa Heraldycznego we Lwowie”, 2, 1909, 8-9, s. 111-115 
Nizio K., Autorstwo poematu „Stanu wdowiego tęskliwego pobożne zabawy i pociechy”, „Pamiętnik Biblioteki Kórnickiej”, 19, 1982, s. 203-212 Podeszwa P., „Obron mnie przed moim przeciwnikiem” (Ek 18, 3). Status wdowy w Opus Lucanum, „Biblica et Patristica Thoruniensia”, 8, 2005, 2, s. $81-100$

Poretsky J. I., Solomon Rysinsky. Salomon Panther Leucorussus, Miensk1983 Sajkowski A., Od Sierotki do Rybeńki. W kręgu radziwittowskiego mecenatu, Poznań 1965

Studia z dziejów górnictwa i hutnictwa, t. 5, red. J. Pazdur, Warszawa 1959 Ślęk L., Muza domowa. Okolicznościowa poezja rodzinna czasów renesansu i baroku, Wrocław 1991 (Acta Universitatis Wratislaviensis, t. 810)

Wasilewski T., Mierzeński Jan, PSB, 21, 1976, s. 18-20

Winiarska-Górska I., Szesnastowieczne przektady Pisma Świętego na język polski 1551-1599 jako gatunek nowożytnej ksiązki formacyjnej, Warszawa 2017

\section{An Anonymous Poem from the Kórnik Library Collection as a Source for the Problem of Widowhood among Calvinists of Lesser Poland in the Late Sixteenth Century}

The article presents a historical analysis of the anonymous poem Stanu wdowiego tęskliwego pobożne zabawy i pociechy [The Longing Status of Widower's Pious Plays and Consolations] (1586-1589) from the manuscript of Kórnik Library of the Polish Academy of Sciences (cat. no. 524, mf. 1419), published for the first time in 1891 by Zygmunt Celichowski, taking into account the notes on the margins he omitted which contain information on the religious formation of the author and secondary use of the text. The hypothetical authorship of Salomon Rysiński is brought up, with the conclusion that it is impossible to make a definite attribution based on the only surviving copy. Then, the article characterises the environment in which the published work was created and its primary purpose to provide a model of behaviour for a widower Calvinist who, instead of remarrying, seeks to enrich himself spiritually through the study of the Scriptures and to prepare for death. Attention is drawn to the original features of the poem: the supra-denominational religious message, the equal treatment of widowed men and women, the high level of the Host's self-reflection and the emotional character of his words, and the public reception through the distribution of copies. In conclusion, the thesis has been put forward that the poem Rozmowy i pociechy o stanie wdowim [Conversations and Consolations on the Status of a Widower], published under the title Stanu wdowiego tęskliwego pobożne zabawy i pociechy, 
is an example of intimist Protestant literature and a valuable source for the study of private emotions of widowed men. The importance of widowerhood as a social problem has also been briefly noted. The author's intention was not to formulate general conclusions on this issue based on the analysis of a single work but to encourage further research into a topic that has been neglected in Polish historiography so far.

Urszula Augustyniak - historyk kultury Rzeczypospolitej polsko-litewskiej w XVI-XVII w., emerytowana profesor Wydziału Historii Uniwersytetu Warszawskiego.

Urszula Augustyniak - historian of the culture of the Polish-Lithuanian Commonwealth in the sixteenth-seventeenth centuries, professor emeritus of the Faculty of History at the University of Warsaw.

E-mail: u.augustyniak@onet.eu 